\title{
Soil contamination and human health: recent contributions
}

\author{
Jaume Bech
}

Published online: 20 August 2021

(C) The Author(s), under exclusive licence to Springer Nature B.V. 2021, corrected publication 2022

\section{Background}

This collection of papers submitted to this Special Issue is mainly an outcome of the Session SSS 8.5, EGU2018 "Soil contamination and human health: advances and problems of risk assessment", the European Geosciences Union (EGU) Conference held in Vienna, April 2018.

This Special Issue contains 21 papers written by authors from 17 countries: Australia, Azerbaijan, Botswana, Bulgaria, Canada, Chile, China, Czech Republic, Finland, Ghana, India, Iran, Italy, Pakistan, Russian Federation, Spain and USA.

This collection of papers is mainly focused on nine research topics:

1. Riverine, flood plain soils.

2. Organic pollutants.

3. Mainly $\mathrm{As} / \mathrm{Pb}$-polluted soils.

4. Waste/waste water.

5. Inorganic pollutants.

6. Forest soils.

7. Source identification analysis.

8. Radionuclides.

9. Geochemical classification of landscapes.

J. Bech $(\bowtie)$

Universitat de Barcelona (UB), Barcelona, Spain

e-mail: jaumebechborras@gmail.com
In the following paragraph, I will summarize the content and main results of these papers published in this Special Issue.

\section{Research topics}

Riverine/flood plain soils

There are six papers dealing with this first topic, riverine, flood plain soils:

Wang et al. (2020) assessed the fractionation and bioavailability of potential toxic elements (PTE) in soil-rice system and the associated health risk from the Yangtze River Delta, China. Results show that the mobility of PTE was in the order: $\mathrm{Cd}>\mathrm{Pb}=\mathrm{Zn}>$ $\mathrm{Ni}>\mathrm{As}=\mathrm{Cr}>\mathrm{Hg}$. Transfer factors (TF) calculated by the ratios of specific fractions of PTE in the soilrice system were used to assess the capacity of different PTE fraction transfer from soil to rice. Soil $\mathrm{Cd}$ contributed more than $80 \%$ of the modified risk assessment code (mRAc). Contrarily, the main contributors to ecological contamination index (ECI) were $\mathrm{As}, \mathrm{Hg}, \mathrm{Pb}$ and $\mathrm{Zn}$. Average values of total target hazard quotient (TTHQ) and risk total (RT) implied that people living in the study area were exposed to both non-carcinogenetic and carcinogenetic risk. As and $\mathrm{Pb}$ were the main contributors to high TTHQ value while As, $\mathrm{Cd}$ and $\mathrm{Cr}$ in rice contributed mostly to $\mathrm{RT}$.

Linnik et al., (2020a, 2020b) studied the content and spatial distribution of $\mathrm{Cu}, \mathrm{Zn}, \mathrm{Pb}$ and $\mathrm{Cr}$ in 
polluted soils of the flood plain of the Seversky Donets river, zone of former Lake Atamaskoe, in KamenskShakhtinsky, Rostov (Russia), based on Geostatistical methods. Extremely high values of these metals concentrations were found. Inverse distance weighted (IDW) interpolation was used. Log-normal Kriging and indicator Kriging techniques were applied to elemental spatial distribution maps and metal probability maps. Similar values of spatial autocorrelation for heavy metals indicated common origin of the geochemical contamination from a single source of man-made waste. The indicator kriging mapped the areas in which soil contamination exceeds the contamination index $\mathrm{Zc}$ groups according to the degree of contamination risk.

Bauer et al. (2021) applied XAFS and XRD methods for describing the $\mathrm{Cu}$ and $\mathrm{Zn}$ adsorption characteristics in hydromorphic soils in southern Russia. The sorption processes described with the Langmuir model suggest that Arenosols are more vulnerable to heavy metal input compared to Fluvisols. XAFS and XRD applied prove the formation of $\mathrm{Cu}(\mathrm{OH})_{2}$ and $\mathrm{ZnCO}_{3}$ on the surface of montmorillonite and calcite. $\mathrm{Cu}$ manifests a higher affinity to adsorption centres than $\mathrm{Zn} . \mathrm{Cu}^{++}$are precipitated on the layered minerals as the coarse-crystalline phase $\mathrm{Cu}_{2}\left(\mathrm{NO}_{3}\right)(\mathrm{OH})_{3}$. These results show that montmorillonite and calcite can be used for the retention of $\mathrm{Zn}$ and $\mathrm{Cu}$ in soils.

Konstantinova et al., (2020a, 2020b) researched the geochemical transformation of soil cover and vegetation in a drained floodplain in the surroundings of the lake Atamanskoye, affected by long-term pollution from rayon industry plants located in the city of Kamensk-Shakhtinsky, lower Don River Basin, southern Russia. The authors evaluated potentially toxic elements and plants by XRF and the contents of their forms by sequential extraction. Results showed that Spolic Technosols and Fluvisols are the most widespread soils within Lake Atamanskoye. These polluted soils are highly enriched in metals over the baseline values and can be divided in two groups: alkaline, very rich in absorbed metal and residual forms, and acidic soils, with higher proportions of exchangeable fractions and higher potential for metal accumulation in their mobile forms which are significant risk factors for the environmental health of the Don basin.

Kebonye et al. (2021) investigated an in-depth human risk assessment of potentially toxic elements
(PTEs)—Pb, Mn, Zn, As, Ti, Rb, Sr, Zr, Ba and Thin highly polluted riverine soils from the Litavka River, in Pfibram (Czech Republic). A portable X-ray fluorescence spectrometer (p-XRFS) was used to measure the PTEs and $\mathrm{Fe}$ content in the soils. Distributions of the PTEs were mapped. The authors calculated the enrichment factor (EF) and pollution index (PI) values and found that $\mathrm{Zn}, \mathrm{As}$ and $\mathrm{Pb}$ were enriched and accounted for the high pollution load index (PLI) levels. They also prepared the EF and PI distribution maps for each PTE. Hazard quotiens (HQ) in different human groups varied. Children had the highest HQs for all PTEs. PTEs with high HQ levels were $\mathrm{As}, \mathrm{Zn}$ and $\mathrm{Pb}$.

Zamulina et al. (2020) assessed the effect of chronic severe soil contamination with $\mathrm{Cu}$ on organic matter and biological activity in Spolic Technosols in the Seversky Donets River flood plain (Russia). Results of the contaminated soil sequential fractionation showed that the chemical fraction composition of $\mathrm{Cu}$ changes when the soil contamination increases. The amount of $\mathrm{Cu}$ compounds associated with SOM and oxides of $\mathrm{Fe}$ and $\mathrm{Mn}$ is higher. The amount of mobile-free fractions of humic and fulvic acids increases. The fractional composition shifts from humic to fulvic-humic. Pollution reduces the activity of urease and deshydrogenase and affects the number and species composition of microorganisms, which was assessed by platecounting culturable microorganisms. Most pollutionresistant were copiotrophic bacteria.

Organic pollutants

Two papers in this Special Issue refer to the second topic, organic pollutants:

Nazarova et al. (2020) researched the influence of destructive bacteria and Red clover (Trifolium pratense $\mathrm{L}$.) on the pesticides degradation in the soil. The authors showed that under laboratory conditions the effective degradation of lindane and DDT soil pollution under the action of introduced destructive bacteria. The concentration of lindane in the soil decreased by $75 \%$ and of DDT by $56 \%$ in 30 days. T. pratense increased pesticide degradation in the soil by $20 \%$. The denaturing gradient gel electrophoresis (DGGE) analysis of microorganism associations introduced in contaminated soil made possible to follow the survival of the introduced associations. The use of microorganisms destructors of pesticides, and plants as well as 
the biodegradation potential of the soil is a possible issue for the recultivation of polluted soils.

Konstantinova et al., (2020a, 2020b) investigated levels and sources of pollution and human health risk assessment of potentially toxic elements (PTEs) and polycyclic aromatic hydrocarbons (PAHs) in urban street dust of Tyumen city, Russia. The authors measured the concentrations of 18 PTEs using ICPMS and 12 PAHs using HPLC, and statistical analysis of data. Concentrations of $\mathrm{Ni}, \mathrm{Cr}, \mathrm{Sb}$ and $\mathrm{Mo}$ and medium and high molecular weight PAHs in urban dust were higher than in soils within the city, which indicates that transport is the origin of these elements. Concentrations of $\mathrm{Cr}, \mathrm{Ni}$ and $\mathrm{Co}$ in the street dust were higher compared to large cities. The carcinogenic risks were low in $70 \%$ of samples. Non-carcinogenic risks were related with $\mathrm{Co}, \mathrm{Ni}, \mathrm{V}$ and $\mathrm{As}$ and were found to be negligible for adults and moderate for children.

Vasiliyeva et al. (2020) proposed an express phytotest for choosing conditions and following process of soil remediation evaluated by germination rate of white clover (Trifolium repens $\mathrm{L}$.) (PhCG). The authors developed this phytotest on the example of grey forest soil contamination with diesel fuel or $\mathrm{Cu}^{++}$ and approbated during more than one year experiments on adsorption bioremediation of petroleumcontaminated soils. The sensitivity of the phytotest values $\mathrm{PhCG}$ is much higher compared to others evaluated by germination of larger seeds. Measuring an additional parameter-root length of the 5-7-d of $T$. repens seedlings may increase the sensitivity of the proposed express phytotest for lower contaminated soils.

Mainly $\mathrm{As} / \mathrm{Pb}$ polluted soils

There are three papers dealing with this topic, mainly $\mathrm{As} / \mathrm{Pb}$ polluted soils:

Pérez-Sirvent et al. (2020) assessed of risk from $\mathrm{Pb}$ intake of soil contaminated in mining activities in the Region of Murcia (SE of Spain) and proposed indicators. Authors studied the nature of the source materials and the parameters that can influence the solubility and bioaccesibility of $\mathrm{Pb}$ from soil intake, especially the values of total $\mathrm{Pb}$ content and 1:2 ratio (soil:water), pH, EC, particle size and mineralogical composition of 186 soil samples. The authors obtained an algorithm represented by different probability distributions of the parameters citated which allow evaluating the risk of health intake by concentration of the $\mathrm{Pb}$ present. Oral bioaccessibility tests were also performed and a mineralogical X-ray diffraction was carried out.

Rimondi et al. (2020) assessed the bioaccessible As in soil and thermal areas of Viterbo, central Italy, and the implications for human health risk. The authors determined As content, sequential extraction and bioaccessibility in soil and travertine samples to investigate the risk of As exposure through accidental ingestion of soil particles. (Pseudo)total content of As in the studied soils range from 17 to $528 \mathrm{mg} / \mathrm{kg}$, higher in soils over travertine $(197 \mathrm{mg} / \mathrm{kg})$ than on volcanic rocks $(37 \mathrm{mg} / \mathrm{kg})$. In travertinic soil, As is associated to the oxide and residual fractions. Bioaccessibility (SBET) is maximum to $139 \mathrm{mg} / \mathrm{kg}$ in soil over travertine. Risk analysis suggests a moderate carcinogenic risk associated with accidental soil ingestion; dermal contact is negligible. Instead, ingestion of thermal water implies a higher carcinogenic and systemic health risk.

Natasha et al. (2020) investigated $\mathrm{As}$ and $\mathrm{Pb}$ toxicity and antioxidant response in spinach from a human health perspective. The authors treated the spinach plants for four weeks with three levels of each potentially toxic element (PTE). The plants accumulated a high concentration of $\mathrm{As}$ and $\mathrm{Pb}$ in roots while less was translocated towards the shoot. This accumulation in plants decreased plant biomass and pigment contents, and provoked oxidative stress by increased $\mathrm{H}_{2} \mathrm{O}_{2}$ production in roots. Moreover, the antioxidant system activated under the $\mathrm{As} / \mathrm{Pb}$ stress. The exposure assessment indices showed high carcinogenic $\left(\mathrm{CR}>10^{-4}\right)$ and non-carcinogenic (HQ > 1) risks due to consumption of $\mathrm{As}$ and $\mathrm{Pb}$ contaminated spinach leaves. Results show As being more toxic to plants and humans than $\mathrm{Pb}$.

Waste/waste water

Two papers in this Special Issue refer to the fourth topic, waste/waste water:

Amponsah et al. (2021) investigated the gastric bioaccesibility via oral and human health risks associated with the distribution of $\mathrm{As}, \mathrm{Cd}, \mathrm{Cr}, \mathrm{Cu}, \mathrm{Hg}, \mathrm{Ni}$, $\mathrm{Pb}, \mathrm{Sb}$ and $\mathrm{Zn}$ in surface soils at the e-waste recycling site at Dagomba Line, Kumasi, Ghana. The concentrations of these potential toxic elements were highly elevated exceeding international soil quality 
guidelines. Bioaccesibility was high for $\mathrm{Pb}(70.8 \%)$, $\mathrm{Cd}(64.1 \%), \mathrm{Cu}(62.3 \%)$ and $\mathrm{Ni}(53.6 \%)$ due to the existence of oxidized species for e-waste burning. Non- carcinogenic effects were unacceptably high (hazard indices $>1$ ) at $50 \%$ of sites and the cancer risk for As workers was also high at five of the sampling sites.

Linnik et al., (2020a, 2020b) focused their study on analysis, assessment and potential sources of $\mathrm{Co}, \mathrm{Ni}$, $\mathrm{Cu}, \mathrm{Cr}, \mathrm{Pb}, \mathrm{Mn}$ and $\mathrm{Zn}$ in soils in the vicinity of lake Atamaskoe, Rostov region, Russia. The authors used multivariate statistical methods such as the hierarchical cluster analysis (HCA), correlation analysis and conditional inference tree (CIT). The investigation was carried out at 81 sample plots. The concentrations of PTE were found to be, in decreasing order: $\mathrm{Zn}<\mathrm{Mn}<\mathrm{Pb}<\mathrm{Cr}<\mathrm{Cu}<\mathrm{Ni}<\mathrm{Co}$. A positive correlation among $\mathrm{Ni}, \mathrm{Cu}, \mathrm{Zn}$ and $\mathrm{HCA}$ results showed the common origin of these elements from waste discharge. Hierarchical CA divided the 81 test sites into five classes based on soil quality and PTE contamination similarity. Regression trees for $\mathrm{Cr}, \mathrm{Pb}$, $\mathrm{Zn}$ and $\mathrm{Cu}$ were verified by the splitting factor including PTE content and soil chemistry factors.

Inorganic pollutants

Two papers in this Special Issue deal with the fifth topic, inorganic pollutants:

Calderon et al. (2021) investigated the occurrence of perchlorate in soil, water, fertilizers, vegetables and fruits collected across Chile and associated human exposure. The highest concentrations of perchlorate were found in soil, lettuce, chard, drinking water and fruits from northern Chile. Perchlorate concentrations in water from three regions exceeded the US EPA advisory level of $15 \mathrm{ng} \mathrm{mL}^{-1}$. Median concentration of perchlorate in non-nitrogenous fertilizers was higher than those in nitrogenous fertilizers. The estimated daily intake of perchlorate via drinking water in Chile is lower than the US EPA's reference dose. The estimated daily intake of perchlorate via vegetables produced in northern Chile were $>3$ times higher than those produced in other regions in Chile. Perchlorate is widely disseminated in the environment but does not pose a hazard for human health.

Shtangeeva et al. (2020) researched the response of wheat and barley seedings to soil contamination with bromides. The authors performed greenhouse pot experiments with these two crops in soil contaminated by bromides of ammonium and neodymium and determined the concentration of elements in the plants and soil by ICP-MS/ICP-OES, previous leaching the samples with tetramethyl ammonium hydroxide. Also, variations in the biomasses and concentration of pigments in the plant leaves were studied. Results showed that wheat and barley accumulate high concentrations of $\mathrm{Br}$ when grown in soil contaminated with this element, but with different response to the soil contamination. Barley was capable of accumulating larger amounts of $\mathrm{Br}$ than wheat, but had lower concentrations of pigments.

Forest soils

Two papers in this Special Issue are concerned with the sixth topic, forest soils:

Yang et al. (2020) investigated the interception effect of potentially toxic elements (PTE) such as Zn, $\mathrm{Cu}, \mathrm{Pb}$, As and $\mathrm{Cd}$ in different ages of Chinese fire pure plantations and mixed coniferous and broadleaved forest stand in Huitong country, Hunan Province, Southern China. Results showed that annual interception of PHE in the mixed stand was greater than in the pure Chinese fir stands. The interception of $\mathrm{Cu}, \mathrm{Cd}, \mathrm{As}$ and $\mathrm{Pb}$ in young stand greater than in old stand in pure Chinese fir plantations and the opposite pattern Zn. The seasonal changes of PHE were greater in winter and spring than in summer and autumn. This study provided useful information about the dynamics of heavy metal interception in forest ecosystems.

Yaneva et al. (2020) researched the bioaccumulation of potentially toxic elements (PTEs) within the soil-plant system in Central Balkan National Park, Bulgaria and analysed the forest ecosystem capacity to transfer toxic elements. The authors studied the transfer of PTEs in soil-plant system in a relatively clean environment in order to assess and map the ecosystem capacity of different types of forest ecosystems to mediate PTEs. Based on in situ observations and sampling, the PTEs concentrations in soil and above ground vegetation were analysed and the bioaccumulation factor estimated. The results highlight the ecological importance of soil as a buffer against pollution especially in areas with high anthropogenic impact and intensive road traffic. 
Source identification analysis

One paper in this Special Issue dealing with the seventh topic, source identification analysis:

Shao et al. (2020) used a finite mixture distribution model (FMDM) and raster-based principal components analysis (RB-PCA) and a positive matrix factorization (PMF) to identify and asportation the sources of five potential toxic elements (PTE) - Cd, $\mathrm{Hg}$, $\mathrm{As}, \mathrm{Pb}$ and $\mathrm{Cr}$ - in soils in Wenzhou City, China. The potential ecological risk assessment showed that the ecological risk level in the study area was low, but $\mathrm{Hg}$ and $\mathrm{Cd}$ could be a threat. Results of FMDM showed that $\mathrm{Cd}$ and $\mathrm{Pb}$ fit a single log-normal distribution, $\mathrm{Hg}$ fit a double log-normal mixed distribution, and $\mathrm{As}$ and $\mathrm{Cr}$ showed a triple log-normal distribution. A map of RB-PCA combined with an analysis of corresponding auxiliary variables indicated that three main sources of five PTEs had been identified and apportioned: (1) parent materials, with high contribution for $\mathrm{Cd}$ and $\mathrm{Pb}$, (2) industrial and agricultural mixed pollution, with high levels for $\mathrm{Hg}$ and (3) mining activities, with high contributions for As and $\mathrm{Cr}$.

\section{Radionuclides}

One paper in this Special Issue deals with the eighth topic, radionuclides:

Kaur and Mehra (2021) carried out a radio-ecological evaluation for risk and dose assessment of soil samples from Solan and Shimia districts, Himachal Pradesh, India. Twenty-six randomly selected soil samples were analysed for radionuclide concentrations $\left({ }^{226} \mathrm{Ra},{ }^{232} \mathrm{Th}\right.$ and $\left.{ }^{40} \mathrm{~K}\right)$ using Nal (Tl) detector. The average concentration (37, 45 and $418 \mathrm{~Bq} \mathrm{Kg}^{-1}$ ), respectively, exceeded the worldwide average reported by UNSCEAR (2018). Radium equivalent activity (Raeq), hazard indices (Hex, Hin) and radioactivity level (ITr, la, AUI) and Clark value were checked and their mean values were safety. Although the risk estimates are low, they can cause cancer incidences, especially in infants and females.

\section{Geochemical classification of landscapes}

One paper deals with the ninth and last topic of this Special Issue, geochemical classification of landscapes.
Rustamov and Ismaylova (2020) developed a medium scale map based on geochemical classification of landscapes in relation to the concentration of potential toxic elements (PTE) and their impact on human healthy applied to Kura intermountain basin (Azerbaijan). The authors used a comparative method of research of the patterns of concentration and migration of PTE in samples of rocks, soils, plants and water in different geochemical landscape types, based on the ratio of biodiversity to biomass. For the first time, a map scheme of diseases caused by anomalous concentrations of PTE of this region was compiled. The authors found very widespread brucellosis in lowlands, hypertension in accumulative plains, dental caries, malaria and respiratory diseases in deserts and oncological and cardiovascular diseases in arid forest of the lowlands and mountainous slopes.

\section{Conclusions}

The content of this Special Issue is of great importance and the 21 papers cover significant aspects of fundamental theoretical and applied research in soil contamination and human health and providing advances to the existing knowledge.

Acknowledgements I would firstly thank the Co-guest Editors Profs. Drs. Elena Korobova, V.V. Ermakov, C. PérezSirvent and M.J. Watts for the valuable collaboration. Moreover, I would like to thank the authors for their contributions and for their patience with the reviewing process as well the reviewers for their observations. I am extremely grateful to Prof. Dr. Ming Hung Wong Editor-in-Chief of EGAH, Johanna Schwarz, Publisher Editor, Suganya Manoharan, Production Editor, Karthick Govindaraju, Production Editor, Mr. Nirmal Sasthankuttypillai, JEO Assistant. Help with English from James Dove and IT assistance from Oriol Bech is also greatly appreciated. Without whose knowledge and experience, this Special Issue could never have been published.

\section{References}

Amponsah, L.O., Dodd, M., \& Darko, G. (2021). Gastric bioaccessibility and human health risks associated with soil metal exposure via ingestion at an E-Waste recycling site Kumasi, Ghana (this special issue).

Bauer, T.V., Pinskii, D.L., Minkina, T.M., Shuvaeva, V.A., Soldatov, A.V., Mandzhieva, S.S., Tsitsuashvili, V.S., Nevidomskaya, D.G., \& Semenkov, I.N. (2021). Application of XAFS and XRD methods for describing the copper 
and zinc adsorption characteristics in hydromorphic soils. (this special issue).

Calderon, R., Arancibia-Miranda, N., Silva-Moreno, E., UnJung, K., \& Palma, P. (2021). Occurrence, distribution and dynamics of perchlorate in soil, water, fertilizers, vegetables and fruits and associated human exposure in Chile. (this special issue).

Kaur, S., Mehra, R. (2021). Dosimetric impact of natural terrestrial radioactivity on residents of Lower Himalayas, India. (this special issue).

Kebonye, N.M., Eze, P.N., Kingsley, J., Agyeman, P.C., Nemecek, K., \& Boruvka, L. (2021). An in-depth human health risk assessment of potentially toxic elements in highly polluted riverine soils, Pribram (Czech Republic). (this special issue).

Konstantinova, E., Minkina, T., Konstantinov, A., Sushkova, S. Antonentko, E., Kurasova, A., \& Loiko, S. (2020). Pollution status and human health risk assessment of potentially toxic elements and polycyclic aromatic hydrocarbons in urban street dust of Tyumen city, Russia (this special issue).

Konstantinova, E.Y., Burachevskaya, M., Mandzhieva, S. Bauer, T., Minkina, T., Chaplygin, V., Zamulina, I., Konstantinov, A., \& Sushkova, S. (2020). Geochemical transformation of soil cover and vegetation in a drained floodplain lake affected by long-term discharge of effluents from rayon industry plants, lower Don River basin, Southern Russia. (this special issue).

Linnik, V., Bauer, T.V., Minkina, T.M., Mandzhieva, S.S., \& Mazarji, M. (2020). Spatial distribution of heavy metals in soils of the flood plain of the Seversky Donets river (Russia) based on geostatistical Methods. (this special issue).

Linnik, V.G., Saveliev, A.A., Bauer, T.V., Minkina, T.M., \& Mandzhieva, S. (2020). Analysis and assessment of heavy metal contamination in the vicinity of lake Atamanskoe (Rostov region, Russia) using multivariate statistical methods. (this special issue).

Natasha, N., Shahid, M., Khalid, S., \& Saleem, M. (2020). Unrevealing arsenic and lead toxicity and antioxidant response in spinach: A human health perspective. (this special issue).

Nazarova, E.A., Egorova, D.O., Nazarov, A.V., \& Anan'ina, L.N. (2020). Influence of destructive bacteria and red clover (Trifolium pratense L.) on the pesticides degradation in the soil. (this special issue).
Pérez-Sirvent, C., Martinez-Martinez, L.B., Martinez-Lopez, S., Hernandez-Perez, C., Garcia-Lorenzo, M.L., Bech, J., \& Martinez-Sánchez, M.J. (2020). Assessment of risk from lead intake in mining areas: proposal of indicators. (this special Issue).

Rimondi, V., Costagliola, P., Lattanzi, C.T., Fornasaro, S., Medas, D., Morelli, G., \& Paolieri, M. (2020). Bioaccessible arsenic in soil of thermal areas of Viterbo, central Italy: implications for human health risk. (this special issue).

Rustamov, G., \& Ismaylova, L.L. (2020). Geochemistry landscape classification: toxicity of chemical elements and their impact on human health. (this special issue).

Shao, S., Hu, B., Tao, Y., Huang, M., Zhou, L., Chen, Q., Shi, Z. (2020). Comprehensive source identification and apportionment analysis of five heavy metals in soils in Wenzhou City, China. (this special issue),

Shtangeeva, I., Niemelä, M., Perämäki, P., Popov, A., Vesavaara, I., \& Suvela, R. (2020). Response of wheat and barley seedlings on soil contamination with bromides. (this special issue).

Vasiliyeva, G.K., Kondrashina, V., Strijakova, E., Pindky, D.L. (2020). Express-phytotest for choosing conditions and following process of soil remediation. (this special issue).

Wang, Y., Xu, W., Li, J., Song, Y., Hua, M., Li, W., Wen, Y., Li, T., \& He, X. (2020). Assessing the fractionation and bioavailability of heavy metals in soil-rice system and the associated health trisk. (this special issue).

Yaneva, R., Zhiyanski, M., \& Dodev, Y. (2020). Bioaccumulation of potentially toxic elements within the soil-plant system in Central Balkan region: analysis of the forest ecosystem capacity to mediate toxic elements. (this special issue).

Yang, A., Chen, J., Wang, X., Guo, H., \& Huang, D. (2020). The interception effect of heavy metals in different types of Chinese fir plantations. (this special issue).

Zamulina, I., Gorovtsov, A.V., Minkina, T.M., Mandzhieva, S.S., Buracheskaya, M.V., \& Bauer, T.V. (2020). Soil organic matter and biological activity under long-term contamination with copper. (this special issue).

Publisher's Note Springer Nature remains neutral with regard to jurisdictional claims in published maps and institutional affiliations. 